\title{
ГЕОМЕХАНИЧЕСКАЯ ИНТЕРПРЕТАЦИЯ ЛОКАЛЬНОЙ СЕЙСМИЧНОСТИ, СВЯЗАННОЙ С ИЗВЕРЖЕНИЯМИ И АКТИВИЗАЦИЕЙ ВУЛКАНОВ ТОЛБАЧИК, КОРЯКСКИЙ И АВАЧИНСКИЙ, КАМЧАТКА, 2008-2012 гГ.
}

\author{
(C) 2016 г. А. В. Кирюхин ${ }^{1}$, С. А. Федотов ${ }^{1}$, П. А. Кирюхин ${ }^{2}$ \\ ${ }^{1}$ Институт вулканологии и сейсмологии ДВО РАН \\ 683006 Петропавловск-Камчатский, бульвар Пийпа, 9, \\ ${ }^{2}$ ООО “Эксиджен Сервисис" \\ 196158 Санкт-Петербург, Пулковское шоссе, 40-1, \\ e-mail: AVKiryukhin2@mail.ru \\ Поступила в редакцию 11.05.2016 г.
}

\begin{abstract}
Локальная сейсмичность при извержении Толбачинского вулкана 2012-2013 гг. и парогазового извержения вулкана Корякский 2008-2009 гг. рассматривается как результат инжекции магмы с формированием даек, силлов и активизации существующих разломов. Для выявления указанных зон из каталогов сейсмических данных КФ ГС РАН выделены плоско-ориентированные кластеры землетрясений. Их последующий пространственно-временной анализ допускает следующую интерпретацию. Лавовому извержению Толбачинского вулкана 27.11.2012 предшествовала инжекция магмы с формированием серии даек запад-север-западного простирания в диапазоне глубин $-4 . . .+3$ км абс. в зоне к юго-востоку от постройки вулкана Плоский Толбачик. Вскрытие указанными дайками субгоризонтальной проницаемой зоны на абс. отметке около нуля привело к образованию силлов и внедрению магмовыводящей дайки вдоль верхней части зоны шлаковых конусов вулкана (угол падения 50, азимут падения $300^{\circ}$ ) в 5.5 км от эпицентра начальной инжекции магмы. Вершинное парогазовое извержение Корякского вулкана 2008-2009 гг. предварялось насыщением магмой корового очага (глубина кровли -3 км абс., поперечник 2.5 км) у юго-западного подножия Корякского вулкана, далее инжекция магмы в субмеридиональной зоне $(7.5 \times 2.5$ км, диапазон глубин $-2 \ldots-5$ км абс.) в северном секторе Корякского вулкана происходила параллельно с вершинным парогазовым извержением. Инжекция магмы в конус Авачинского вулкана (2010 г.) происходила с насыщением конуса силлами (в диапазоне отметок $+1600 \ldots+1900$ м абс.) и дайками (преимущественно северо-западного простирания).
\end{abstract}

DOI: $10.7868 / \mathrm{S} 0203030616040040$

\section{1. ВВЕДЕНИЕ}

При побочных извержениях андезибазальтовых вулканов и при трещинных извержениях в их радиальных зонах шлаковых конусов образуются новые магматические каналы, питающие эти извержения. Такие питающие магматические каналы, которые образуются перед началом извержений и во время их развития, имеют форму даек, силлов, лакколитов и штоков. Изучение образования, строения и свойств таких тел является важными задачами вулканологии, теории формирования геотермальных, нефтяных, газовых и рудных месторождений. Целью данной работы является анализ возможности оценки геометрии плоско-ориентированных питающих магматических каналов вулканов (даек и силлов) по сейсмическим данным с последующей геомеханической интерпретацией полученных оценок.
Исходные представления о глубине и размерах питающих магматических очагов вулкана Плоский Толбачик изложены в статье С.А. Федотова и др. [2011]. Эти представления основаны на геологических, сейсмологических, геодезических данных и моделировании эволюции выплавления магматической камеры под вулканом Плоский Толбачик. В соответствии с этими представлениями под вулканом Плоский Толбачик располагается периферический магматический очаг с поперечными размерами до 6 км, кровля очага находится на глубине 2 км ниже уровня моря, вертикальная мощность 3.2-3.9 км, объем 40-70 км³.

Существуют геолого-геофизические предпосылки для приблизительной оценки геометрии магматического очага под Авачинским вулканом в форме эллипсоида [Федотов, 2006; Федотов и др., 2007]: положение верхней кромки магматического очага оценивается в пределах интервала от ну- 
левой отметки уровня моря и не ниже 2 км от этого уровня, размер горизонтальной и вертикальной полуосей эллипсоида по изотерме $900^{\circ} \mathrm{C}$ не меньше 2.3 и 1.53 км, по изотерме $700^{\circ} \mathrm{C}-4.5$ и 3 км соответственно. При длительности эксплуатации подземной циркуляционной системы в течение 100 лет блок нагретых пород объемом порядка 50 км³ может обеспечить получение около 250 МВт электроэнергии [Федотов, 2006; Федотов и др., 2007]. В связи с возобновившейся разведкой источников геотермального тепло- электроснабжения в районе Корякско-Авачинской группы вулканов (Р.И. Пашкевич, личное сообщение, 2015 г.), уточнение условий распределения активных магматических тел и механизмов транспорта магмы в питающих каналах вулканов является достаточно актуальной задачей.

Отметим ряд результатов, полученных при исследованиях БТТИ, 1975-1976 гг.: вертикальный подъем магм по трещинам перед образованием крупных новых конусов I, II, III и VIII; образование неглубокого силла, питавшего малые конусы IV-VII; образование лакколита под конусом I, основание которого поднималось до появления лавовых бокк и стало опускаться при большом истечении лав из них; вероятное внедрение силлов из периферического очага ПТ на Ю-З при провале на 300 м его вершинной кальдеры и др. [Большое трещинное ..., 1984].

Вулканы и коровые магматические очаги являются продуктами подъема магм из первичных магматических очага на глубинах 150-200 км [Федотов, 2006, и др.]. Коровые магматические очаги подпитываются магмой из первичных магматических резервуаров (зон аккумуляции магмы) и являются источником для образования наклонных даек, силлов и даек, включающих питающие дайки, обеспечивающих извержения магмы на поверхность и формирование построек самих вулканов. Образование даек и силлов при их начальном внедрении через вязкую оболочку магматических очагов приводит к увеличению размеров последних.

Многие дайки “замерзают” во вмещающих породах не достигая выхода на поверхность, некоторые изменяют ориентацию в процессе распространения и преобразуются в силлы. Изменения ориентации даек и преобразования даек в силлы часто наблюдаются в стратиформных резервуарах, осложненных сбросами (нормальными разломами). Обзор палеовулканологических данных и существующих термогидродинамических моделей магматических очагов показывает следующее [Gudmundsson, 2012]: 1) многие коровые магматические очаги формируются из силлов; 2) активные коровые магматические очаги осуществляют инжекцию магмы в связанные с ними вулканы, большинство очагов находится в частично расплавленном (поровом) состоянии;
3) термически стабильная форма магматических очагов - эллипсоид; 4) при гидроразрыве и инжекции даек необходимо учитывать избыточное давление магмы (прочность вмещающих горных пород на разрыв, 1-6 МПа), абсолютное давление магмы и общее литостатическое давление (стресс); 5) в процессе извержения избыточное давление экспоненциально падает до тех пор, пока дайка не утратит гидравлическую связь с очагом; 6) в периоды покоя давление магмы в очаге должно быть равным общему литостатическому давлению; 7) условия гидроразрыва на поверхности магматического очага достигаются двумя способами: увеличением абсолютного давления магмы в очаге в результате инжекции из питающего магматического резервуара или снижением горизонтального стресса в результате регионального растяжения; 8) локальное поле напряжений в окрестности магматического очага зависит от формы очага, его глубины, геомеханических свойств и характеристик слоистости вмещающих горных пород.

Изложенное выше показывает, что процессы инжекции магмы из коровых магматических очагов с образованием даек и силлов в результате магморазрыва являются в большой степени аналогичными процессам инжекции (нагнетанию) флюидов в скважины с гидроразрывом и образованием трещин во вмещающих формациях. В связи с этим, в дальнейшем изложении применительно к инжекции магмы мы будем использовать термин магморазрыв для обозначения процесса формирования плоско-ориентированных структур (даек, наклонных даек, силлов, крупных трещин и разломов) при активизации коровых магматических очагов вулканов.

Данные по инжекции флюидов в скважины на нефтяных, газовых и геотермальных месторождениях широко используются для оценки напряженного состояния массива. Многочисленные экспериментальные данные показывают, что плоскость трещины гидроразрыва ориентируется перпендикулярно к оси минимальных напряжений.

Процесс гидроразрыва осложняется, если существует возможность “замерзания” флюида, в этом случае необходимы большие расходы для поддержания теплового баланса выше солидуса, поэтому магматические инжекции в виде даек должны иметь большее раскрытие (до 1-10 м), что обосновывается как теоретическими расчетами [Большое трещинное ..., 1984], так и геологическими наблюдениями.

Для описания напряженного состояния горного массива используются три главных напряжения: вертикальный стресс (Sv), максимальный горизонтальный стресс (Shmax) и минимальный горизонтальный стресс (Shmin) [Zoback, 2010, p. 8-12]. Применительно к инжекции магмы в 
питающей системе вулкана можно предполагать, что в условиях горизонтального растяжения земной коры (рифтовые зоны, грабены, Sv $>$ Shmax $>$ $>$ Shmin) преимущественно будут формироваться дайки, в зонах горизонтального сжатия земной коры (горсты, Shmax > Shmin > Sv) - более благоприятные условия для внедрения силлов. Необходимо также учитывать, что инжекция магмы может вызывать изменения напряженного состояния в окрестности вулканического аппарата в процессе подготовки и извержения вулкана, т.е. реализация инжекции магмы (дайка или силл) зависит от времени.

Создание новых трещин гидроразрыва и активизация существующих разломов сопровождается микросейсмичностью, связанной с формированием сдвиговых трещин в примыкающей к основной асейсмической трещине гидроразрыва зоне (триггерная сейсмичность). Поэтому можно предполагать, что ориентация плоскостей, аппроксимирующих кластеры микроземлетрясений, совпадает с трещинами гидроразрыва при инжекции (внедрении) магмы. Магнитуды землетрясений для сдвигов с амплитудами 0.1 мм-1 см при протяженности трещин в первые сотни метров оцениваются в диапазоне от 1 до 2 (Кs от 3.5 до 5.5), что соответствует чувствительности локальных сейсмических сетей, действующих в районе Толбачинского вулкана и Корякско-Авачинской группы вулканов.

В данной работе процесс внедрения магмы в трещинно-пористую среду рассматривается по аналогии с геофильтрацией (где в качестве флюида выступает магма), что является в некоторой степени развитием идей В.В. Иванова [2015] о природе микросейсмичности при внедрениях магмы. Такая постановка задачи также мотивирована фактическими данными, изложенными в работе [Sigmundsson et al., 2015], где описывается инжекция магмы из магматического очага вулкана центрального типа Бартарбунга (Исландия), происходившее в августе 2014 г. и сопровождавшееся распространением дайки на расстояние 45 км.

С учетом вышесказанного, целью данного исследования являлось выявление указанных выше плоско-ориентированных кластеров землетрясений на примере сейсмических событий предшествовавших лавовому извержению Толбачинского вулкана 27.11.2012 и активизации КорякскоАвачинской группы вулканов 2008-2009 гг. (раздел 2), последующий анализ возможного пространственного распределения даек и силлов в постройках и фундаменте указанных вулканов (разделы 3 и 4), использование диаграмм Мора для оценки соответствия геомеханическим критериям сдвиговых трещин и давления магмы, необходимого для их активизации (раздел 5). В значительной степени данное исследование опирается на полученные и опубликованные ранее материалы по лавовому извержению Толбачинского вулкана 2012-2013 г., анализ которых содержится в разделе 3.1 .

\section{2. ИСХОДНЫЕ ДАННЫЕ И АЛГОРИТМ ВЫБОРА ПЛОСКО-ОРИЕНТИРОВАННЫХ КЛАСТЕРОВ МИКРОЗЕМЛЕТРЯСЕНИЙ}

\section{1. Исходные данные}

Для регистрации локальных землетрясений в районе Толбачинских вулканов в 2012-2013 гг. использовалась Ключевская сеть радиотелеметрических станций КФ ГС РАН, которая состоит из 12 станций. Пять из них (рис. 1) могут регистрировать землетрясения с магнитудами от -1 или 2 вулкана Плоский Толбачик.

В работе [Федотов и др., 2014] построены и проанализированы вертикальные геофизические разрезы по рассматриваемому району с нанесением гипоцентров зарегистрированных землетрясений. Абсолютная точность расчета координат гипоцентров и эпицентров микроземлетрясений по рассматриваемому времени извержения вулкана Толбачик 2012 г. оценивается в 3 км [Землетрясения ..., 2014].

В работе [Кугаенко и др., 2014] выделяются этапы сейсмической активизации и ее пространственное распределение в районе вулкана Плоский Толбачик перед началом извержения 27.11.2012, в том числе отмечается статистически значимая сейсмическая активизация с июля по октябрь 2012 г. (Ks = 4-6), выход уровня сейсмичности на экстремально высокий уровень за три недели до начала, и наиболее сильные землетрясения (Ks = 7-9) в последние часы перед его началом. После начала извержения (30.11-7.12.2012) сейсмическая активность переместилась на 10 км к югу в Толудскую зону землетрясений $(\mathrm{Ks}=5.2-11.3)$.

Регистрация сейсмичности Авачинско-Корякской группы вулканов производится шестью станциями (рис. 2). Абсолютная точность расчета координат гипоцентров и эпицентров микроземлетрясений по рассматриваемому району Корякско-Авачинской группы вулканов оценивается в 1 км [Землетрясения ..., 2014].

Из каталогов также видно, что близкие по времени и месту землетрясения имеют близкие погрешности определения времени, т.е. сдвигаются в одну сторону - это позволяет предполагать, что относительная точность определения координат рассматриваемых землетрясений намного ниже для кластеров событий, близких по времени и пространству. Например, события VLN127128VLN127172 [Землетрясения ..., 2014], соответствующие кластеру 39 (таблица), показывают на порядок меньшее стандартное отклонение погрешности определения времени, чем все события из рассматриваемого ниже каталога. Исходя из это- 


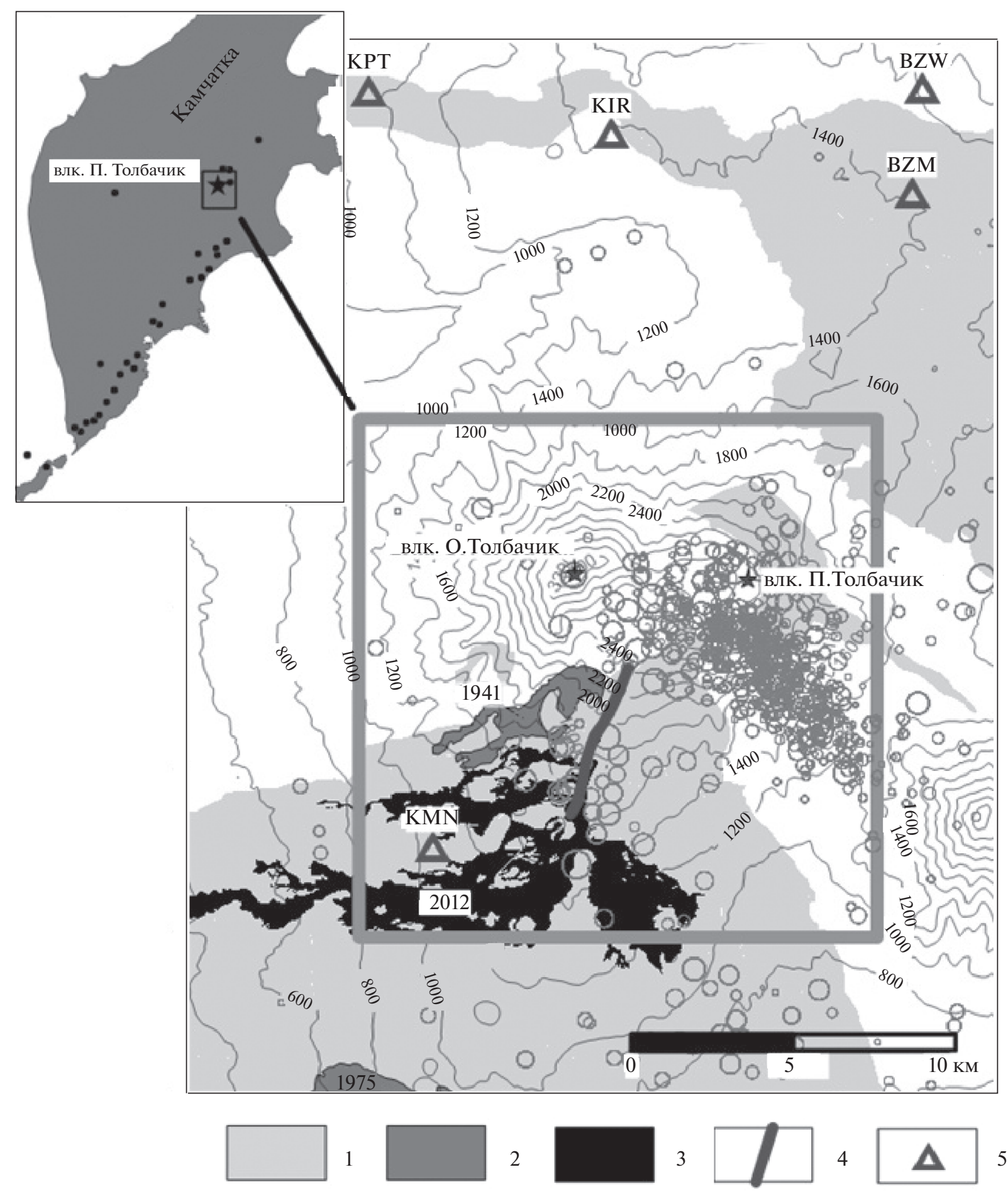

Рис. 1. Схема района Толбачинского вулкана.

1 - лавы голоценового возраста; 2 - лавы исторических извержений (прорыв 1941 г. и Северный прорыв 1975 г.); 3 лавы извержения 2012-2013 гг.; 4 - проекция эруптивной трещины ТТИ 27.11.2012 на поверхности; 5 - сейсмостанции КФ ГС РАН с сокращенными названиями сейсмостанций. Эпицентры землетрясений 2012-2013 гг. (данные КФ ГС PAН) показаны кружками (пропорционально энергетическому классу Ks от 2.6 до $11.3, \mathrm{M}=0.5 \mathrm{Ks}-0.75$ ), внутренний прямоугольник - границы 3D модели на рис. 5. Изолиниями показана топографическая поверхность. 


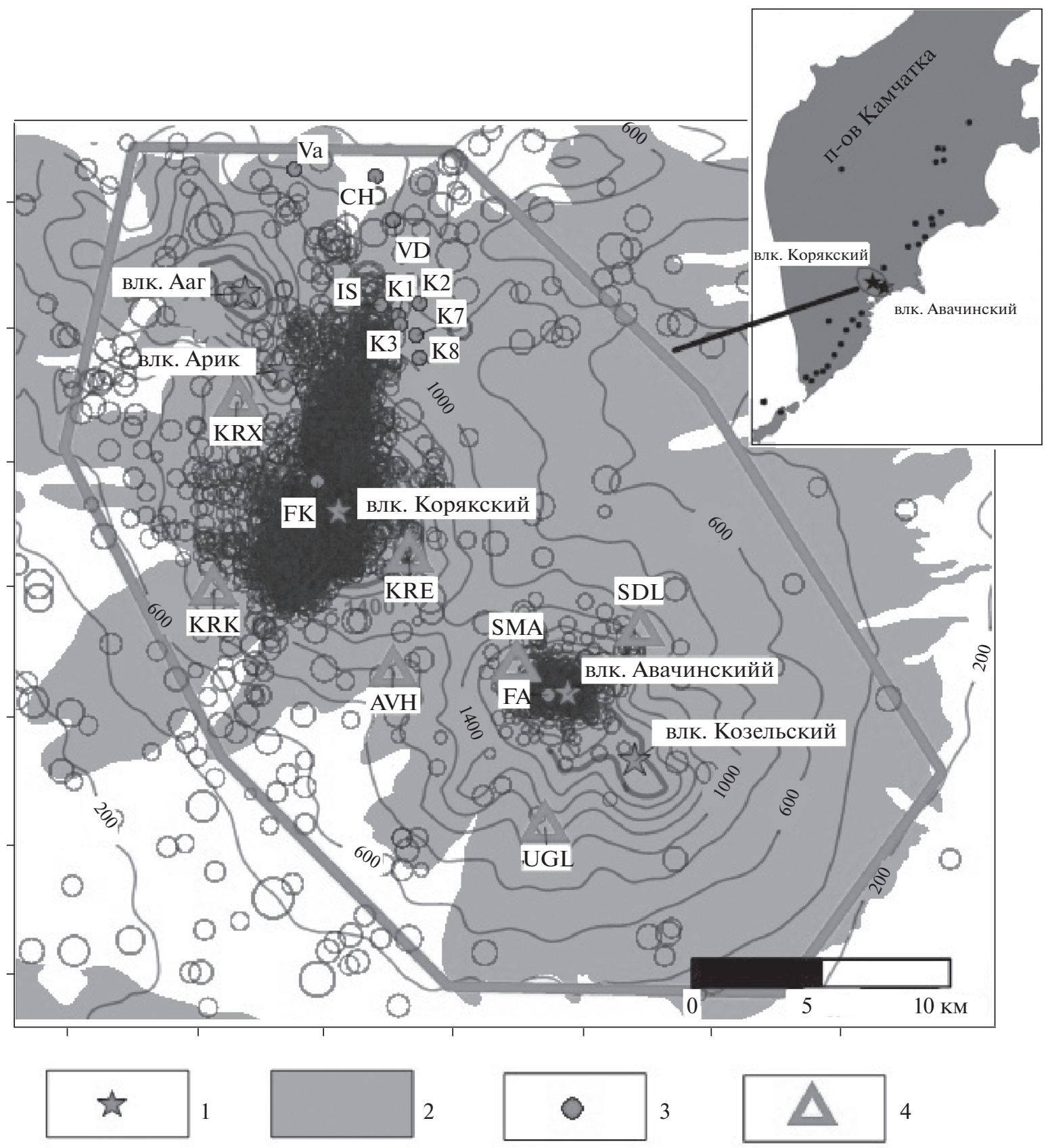

Рис. 2. Схема Корякско-Авачинского вулканогенного бассейна.

1 - вершины вулканов Авачннский, Корякский, Козельский, Арик и Ааг; 2 - продукты извержений вулканов, указанных выше; 3 - термопроявления: FA - фумаролы Авачинского вулкана, FK - фумаролы Корякского вулкана; термоминеральные источники: K1, K2, K3, K7, K8 - Корякские Нарзаны, IS - Изотовский, VD - Водопадный, СН - Чистинские, Va - Вакинский; 4 - сейсмостанции КФ ГС РАН. Эпицентры землетрясений 2000-2013 гг. (данные КФ ГС PAН) показаны кружками (пропорционально энергетическому классу Ks от 1.1 до 8.5, M =0.5Ks-0.75). Внутренний полигон - границы 3D модели на рис. 6. Изолиниями показана топографическая поверхность, разметка осей -5 км.

го, можно предполагать, что при кластеризации землетрясений, близких по времени и пространству, относительная ошибка определения их координат будет допустимой для идентификации плоско-ориентированных объектов с размерами в первые км. Очевидно также, что при случайном сдвиге координат вероятность не попасть в плоско-ориентированный кластер намного больше, чем туда попасть, поэтому, если события геометрически упорядочиваются, несмотря на ошибки 
Выделенные плоско-ориентированные кластеры землетрясений из каталога сейсмических событий по району Толбачинского вулкана за 2012-2014 гг. и параметры плоскостей, их аппроксимирующих

\begin{tabular}{|c|c|c|c|c|c|c|c|c|}
\hline $\begin{array}{c}\# \# \\
\text { кластера }\end{array}$ & \begin{tabular}{|c} 
Угол \\
падения, \\
град
\end{tabular} & $\begin{array}{c}\text { Азимут } \\
\text { падения, } \\
\text { град }\end{array}$ & $X, \mathrm{~m}$ & $Y, \mathrm{~m}$ & $Z$, м абс. & \begin{tabular}{|c|} 
Начало кластера \\
DD/MM/YY \\
HН:MM
\end{tabular} & $\begin{array}{c}\text { Число } \\
\text { землетрясений } \\
\text { в кластере }\end{array}$ & $\begin{array}{c}\text { Площадь } \\
\text { кластера, } \\
\text { км }^{2}\end{array}$ \\
\hline 18 & 80 & 137 & 588041 & 6185570 & -2369 & $25.11 .1210: 56$ & 8 & 8.8 \\
\hline 19 & 25 & 230 & 589355 & 6185175 & -3256 & 25.11.12 20:29 & 27 & 6.6 \\
\hline 20 & 44 & 148 & 588412 & 6185393 & -2422 & $25.11 .1222: 00$ & 19 & 0.7 \\
\hline 21 & 32 & 250 & 588749 & 6185321 & -2893 & 26.11.12 1:12 & 28 & 0.6 \\
\hline 22 & 58 & 74 & 588183 & 6185916 & -1727 & 26.11.12 6:06 & 27 & 8.8 \\
\hline 23 & 77 & 209 & 587489 & 6186380 & -1887 & 26.11.12 6:59 & 31 & 1.6 \\
\hline 24 & 62 & 6 & 588037 & 6185744 & -2536 & 26.11.12 9:29 & 17 & 17.9 \\
\hline 25 & 42 & 112 & 587506 & 6185373 & -3030 & $26.11 .1215: 12$ & 9 & 15.3 \\
\hline 26 & 46 & 233 & 587490 & 6186646 & -1162 & $26.11 .1217: 02$ & 11 & 10.5 \\
\hline 27 & 52 & 138 & 588833 & 6185808 & -1454 & $26.11 .1218: 50$ & 20 & 16.1 \\
\hline 28 & 27 & 245 & 589936 & 6184132 & -3135 & 26.11.12 19:51 & 17 & 3.7 \\
\hline 29 & 61 & 53 & 587366 & 6185779 & -263 & $26.11 .1220: 58$ & 12 & 1.8 \\
\hline 30 & 59 & 20 & 586981 & 6185946 & -818 & 26.11.12 23:04 & 12 & 9.7 \\
\hline 31 & 62 & 208 & 589346 & 6185416 & -1780 & $26.11 .1223: 16$ & 13 & 21.2 \\
\hline 32 & 63 & 18 & 587227 & 6186504 & -797 & $26.11 .1223: 45$ & 7 & 10.4 \\
\hline 33 & 60 & 197 & 588391 & 6186634 & -2127 & 27.11.12 0:19 & 7 & 7.5 \\
\hline 34 & 75 & 192 & 585967 & 6186785 & -2147 & 27.11.12 0:38 & 6 & 21.2 \\
\hline 35 & 74 & 213 & 591075 & 6183134 & -1053 & 27.11.12 2:26 & 6 & 5.7 \\
\hline 36 & 83 & 98 & 589811 & 6184397 & -1122 & 27.11.12 3:16 & 6 & 1.5 \\
\hline 37 & 3 & 135 & 589307 & 6183391 & -177 & 27.11.12 3:55 & 9 & 13.1 \\
\hline 38 & 55 & 300 & 583378 & 6183079 & 302 & 27.11.12 5:35 & 6 & 4.0 \\
\hline 39 & 7 & 196 & 583269 & 6181414 & -35 & 27.11.12 7:09 & 12 & 8.9 \\
\hline
\end{tabular}

Примечание. $X, Y, Z$ - координаты центров кластеров (система координат UTM WGC-84).

измерения их координат - значит в этом есть определенный физический смысл.

\section{2. Алгоритм выбора плоско-ориентированных кластеров микроземлетрясений и оценки параметров соответствующих плоскостей}

Для поиска кластеров разработана программа с использованием Java SE Development Kit 8 (jdk8u40-windows-x64). Критериями сравнения для включения нового объекта в кластер были выбраны: 1) близость по времени ( $\Delta t=1$ сутки); 2) близость по расстоянию в горизонтальной плоскости $(\Delta R<6 \mathrm{Kм}) ; 3$. Близость к плоской ориентации (расстояние от объекта до плоскости $\Delta Z$ не более 200 м). Далее анализировались только кластеры с числом элементов более $N>5$.

Выбор кластеров. При выполнении программы для проверки указанных выше 3-х условий выполняется просмотр всех исходных землетрясений из основного списка в цикле. Если полученный в итоге размер кластера $N>5$ элементов, кла- стер считается сформированным и добавляется в список кластеров. Процедура повторяется до тех пор, пока основной список элементов не станет пустым.

Расчет параметров плоско-ориентированного кластера. Входные данные - список элементов кластера. Каждый элемент $i$ содержит координаты $\left(x_{i}, y_{i}, z_{i}\right)$. Для $n$ (число элементов в кластере) точек с координатами $\left(x_{i}, y_{i}, z_{i}\right)$ уравнение аппроксимирующей плоскости $z=a x+b y+c$ рассчитываем методом наименьших квадратов. Таким образом, решение сводится к решению системы линейных уравнений (СЛУ):

$$
\left[\begin{array}{ccc}
\sum x_{i}^{2} & \sum x_{i} y_{i} & \sum x_{i} \\
\sum x_{i} y_{i} & \sum y_{i}^{2} & \sum y_{i} \\
\sum x_{i} & \sum y_{i} & n
\end{array}\right]\left[\begin{array}{l}
a \\
b \\
c
\end{array}\right]=\left[\begin{array}{c}
\sum x_{i} z_{i} \\
\sum y_{i} z_{i} \\
\sum z_{i}
\end{array}\right] .
$$

СЛУ решается методом Крамера.

Таким образом, получаем коэффициенты $a, b, c$ для уравнения плоскости $z=a x+b y+c$. Далее, pacсчитываем единичный нормальный вектор к ап- 
проксимирующей плоскости $\mathbf{n}=(a / \Delta, b / \Delta,-1 / \Delta)$, где $\Delta$ - определитель СЛУ. После чего вычисляются геологические характеристики: угол падения $\beta=\arccos (1 / \Delta) \times 180 / 3.142$ и азимут падения $\operatorname{arctg}(a / b) \times 180 / 3.142$.

Анализ чувствительности алгоритма выбора плоско-ориентированных кластеров по отношению к времени и пространственной близости показывает, что указанные выше критерии обеспечивают физически и геологически приемлемые результаты выборки.

По данным из каталога локальных землетрясений КФ ГС РАН (1262 события за период (1.01.2012-31.12.2013) в районе Толбачинских вулканов выделяется 310 событий, формирующих 22 плоско-ориентированных кластера землетрясений, непосредственно предшествующих извержению вулкана 27.11.2012. В таблице приводятся результаты выделения плоско-ориентированных кластеров землетрясений с учетом критериев, изложенных выше, а также структурно-геологические характеристики соответствующих плоскостей (угол падения, азимут падения, координаты центров кластеров, время реализации и число землетрясений). Изменение величины интервала времени $\Delta t$ при выборке плоско-ориентированных кластеров в большую сторону (до 2 сут) не влияет существенно на результат выделения кластеров, что свидетельствует о том, что каждая новая дайка или силл не совпадают пространственно с предшествующими. Заметим также, что после начала извержения 27.11.2012 и до конца 2013 г. выделяются только 4 плоско-ориентированных кластера, соответствующих Толудскому облаку землетрясений (30.11.2012-04.12.2012) в 10-ти км южнее центров извержения. Один из указанных кластеров интерпретируется как силл на абс. отм. -260 м, что может указывать на его гидравлическую связь с системой магмовыводящих каналов извержения 27.11.2012 (кластеры 37 и 39, таблица).

За период с января 2000 г. по февраль 2013 г. в постройках и фундаменте Корякско-Авачинской группы вулканов по данным КФ ГС РАН зарегистрировано 3922 землетрясения. В результате обработки указанного выше набора данных по методике, изложенной выше, из них выделяется 1310 землетрясений, формирующих 164 плоскоориентированных кластера в период с января 2008 г. по август 2011 г.

\section{3. Анализ чувствительности алгоритма выбора плоско-ориентированных кластеров от случайной составляющей погрешности определения координат микроземлетрясений}

По данным В.В. Иванова (Личное сообщение, 2015 г.) кластеры вулканических землетрясений состоят из тысяч или десятков тысяч событий и при усилении сейсмической активности слива- ются в сплошную запись, напоминающую запись вулканического дрожания. Каждое новое землетрясение вступает на фоне предыдущего, выделить вступления объемных $\mathrm{P}$ и $\mathrm{S}$ волн и определить его местоположение классическим сейсмологическим методом удается лишь для единичных событий.

Анализ чувствительности определения параметров плоско-ориентированных кластеров микроземлетрясений (угла падения и азимута падения) от случайной составляющей ошибок определения координат землетрясений осуществлен на примере каталога данных землетрясений по району Толбачинского вулкана (2012-2013 гг.) следующим образом. Координаты землетрясений сдвигались на программно сгенерированные случайные величины, распределенные по нормальному закону (Гауссовское распределение) с различными среднеквадратическими отклонениями $\sigma(125,250,500,1000,3000$ м). После этого по алгоритму, изложенному в разделе 2.2 , проводился выбор плоско-ориентированных кластеров землетрясений и оценка характеристик кластеров (угол падения и азимут падения), которые затем представлялись в графическом виде в полярной системе координат при различных значениях $\sigma$. Результаты анализа показывают, что сохранение характеристик последовательности плоско-ориентированных кластеров достигается при случайной составляющей $\sigma$ не более 0.5 км. Выявлено также, что при увеличении критерия близости элементов кластера к плоскости возможно объединение пространственно близких кластеров.

\section{3. ГЕОМЕХАНИЧЕСКАЯ ИНТЕРПРЕТАЦИЯ: ПОСЛЕДОВАТЕЛЬНОСТЬ ИНЖЕКЦИИ МАГМЫ 25.11.2012-27.11.2012 ПЕРЕД ИЗВЕРЖЕНИЕМ ТОЛБАЧИНСКОГО ВУЛКАНА}

\section{1. Интерпретация спутниковых, геодеформационных данных и полевых измерений трещиноватости}

Последнее трещинное извержение на южном склоне Толбачинского вулкана началось 27.11.2012 и продолжалось в течение 9-ти месяцев, общий объем изверженных продуктов оценивается $0.55 \mathrm{KM}^{3}$ при площади 36 км$^{2}$, расход магмы достигал в начале извержения $440 \mathrm{~m}^{3} / \mathrm{c}$, в ходе извержения постепенно уменьшался со 140 до $18 \mathrm{~m}^{3} / \mathrm{c}$ [Belousov et al., 2015]. Это извержение существенно обновило ландшафт вулкана после Большого трещинного Толбачинского извержения 1975-1976 [Федотов и др., 1991].

Геодеформационные изменения в процессе извержения 2012-2013 гг. оценивались с использованием повторных радарных спутниковых съемок (interferometric synthetic aperture radar (InSAR)), при этом использованы данные Canadian Space 


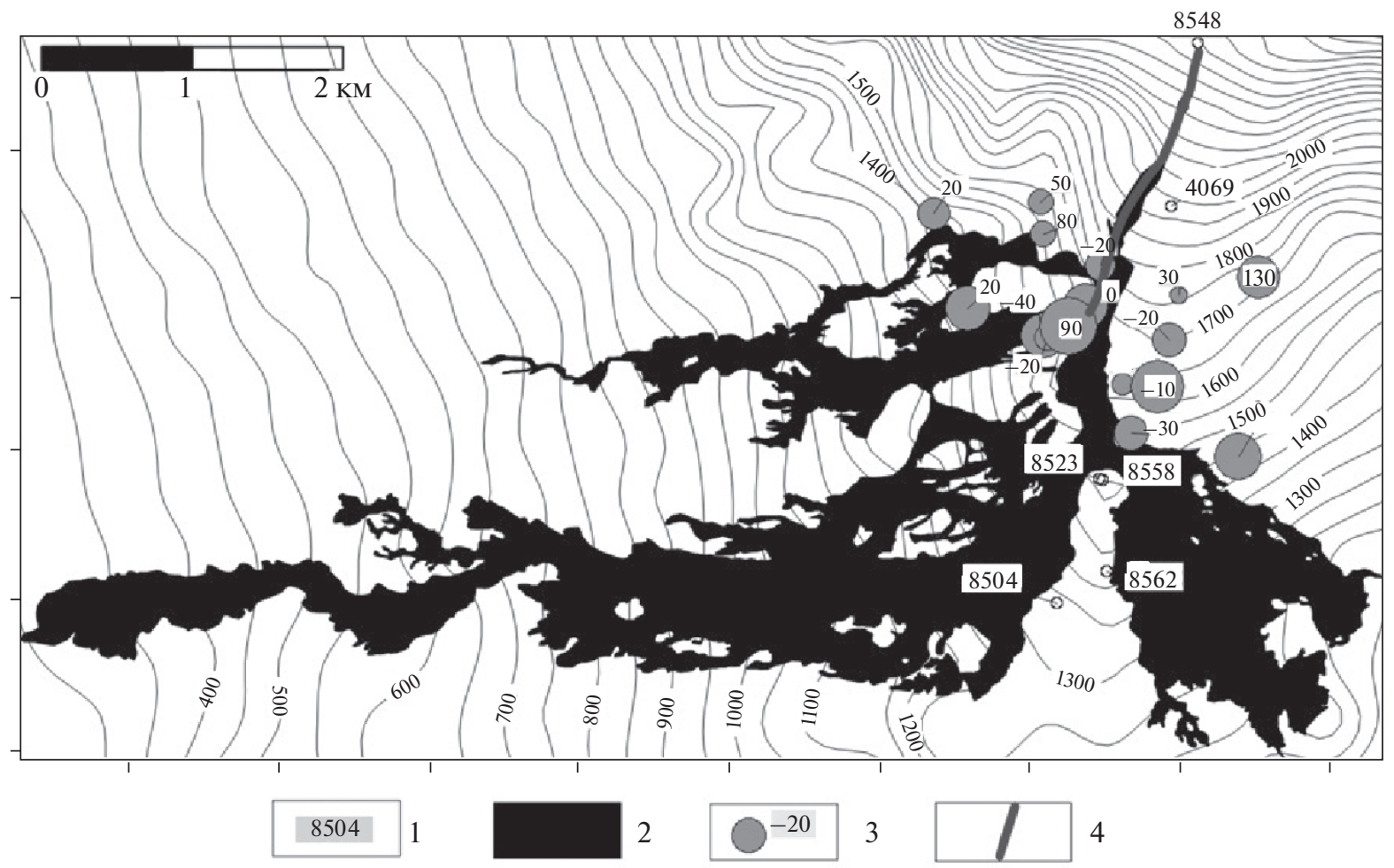

Рис. 3. Карта эпицентров последнего предшествовавшего кластера землетрясений, лавовых потоков и точек замера трещин в районе Толбачинского извержения 2012-2013 гг.

Схема точек замеров трещин в районе Толбачинского извержения 2012-2013 гг., некоторые из них показаны на фото рис. 4. Положение участка соответствует контурам лавового потока Толбачинского извержения 2012-2013 гг. Положение лавовых потоков Толбачинского извержения 2012-2013 гг. на Камчатке показано на рис. 1. 1 - точки замеров трещин (цифры внутри прямоугольников соответствуют фото на рис. 4); 2 - контуры лавовых потоков Толбачинского извержения 2012-2013 гг. [Volynets et al., 2013]; 3 - эпицентры локальных землетрясений UTC 7:25-7:57 27 ноября 2012 (данные КФ ГС РАН), цифры - абс. отметки глубин в м (землетрясения соответствуют кластеру 39, см. таблицу); $4-$ проекция эруптивной трещины ТТИ 27.11.2012 на поверхности. Изолиниями показана топографическая поверхность, разметка осей -2 км.

Agency's RADARSAT-2 и Italian Space Agency's COSMO-SkyMed [Lundgren et al., 2015]. По климатическим условиям (снежный покров) сравнение интерферограмм возможно только для съемок в августе-сентябре 2012 и 2013 гг. 3D геомеханическая модель описывает наблюдаемые за рассматриваемый интервал времени (год) деформации как результат горизонтального растяжения в результате внедрения радиальной дайки Толбачинского вулкана (угол падения $80^{\circ}$ в запад-север-западном направлении).

Мониторинг геодеформационного режима по данным GPS наблюдений [Кугаенко и др., 2015] показывает синхронное с началом извержения 27.11.2012 резкое проседание на 30-40 мм и смещение по направлению к центру извержения (азимут $\approx 210^{\circ}$ ) в зоне Ключевской группы вулканов на расстоянии 45-70 км. Указанные наблюдения указывают на гидравлическую связь магматических питающих систем Ключевской группы вулканов и Толбачинских вулканов.

Полевые измерения параметров открытых трещин в районе извержения в сентябре 2013 г., выполненные нами, показывают: 1. Простирание основной магмовыводящей трещины $25^{\circ}$; 2. Преобладание открытых (до $0.5-1.0$ м) тре-

Рис. 4. Фото трещин в точках измерений, изображенных на рис. 3.

Фото вверху показывает полигональные трещины (т.н. 8504, 8523, 8558, 8562) (полигональные открытые трещины указывают на условия радиального растяжения, возможные при значительном превышении вертикального стресса над горизонтальным, что может происходить при внедрении силлов). Фото внизу - открытые линейные трещины с преобладающим азимутом простирания $340^{\circ}$ (т.н. 4069) (открытые линейные трещины под углом $45^{\circ}$ к основной магмовыводящей трещине указывают на ее сдвиговый характер). 

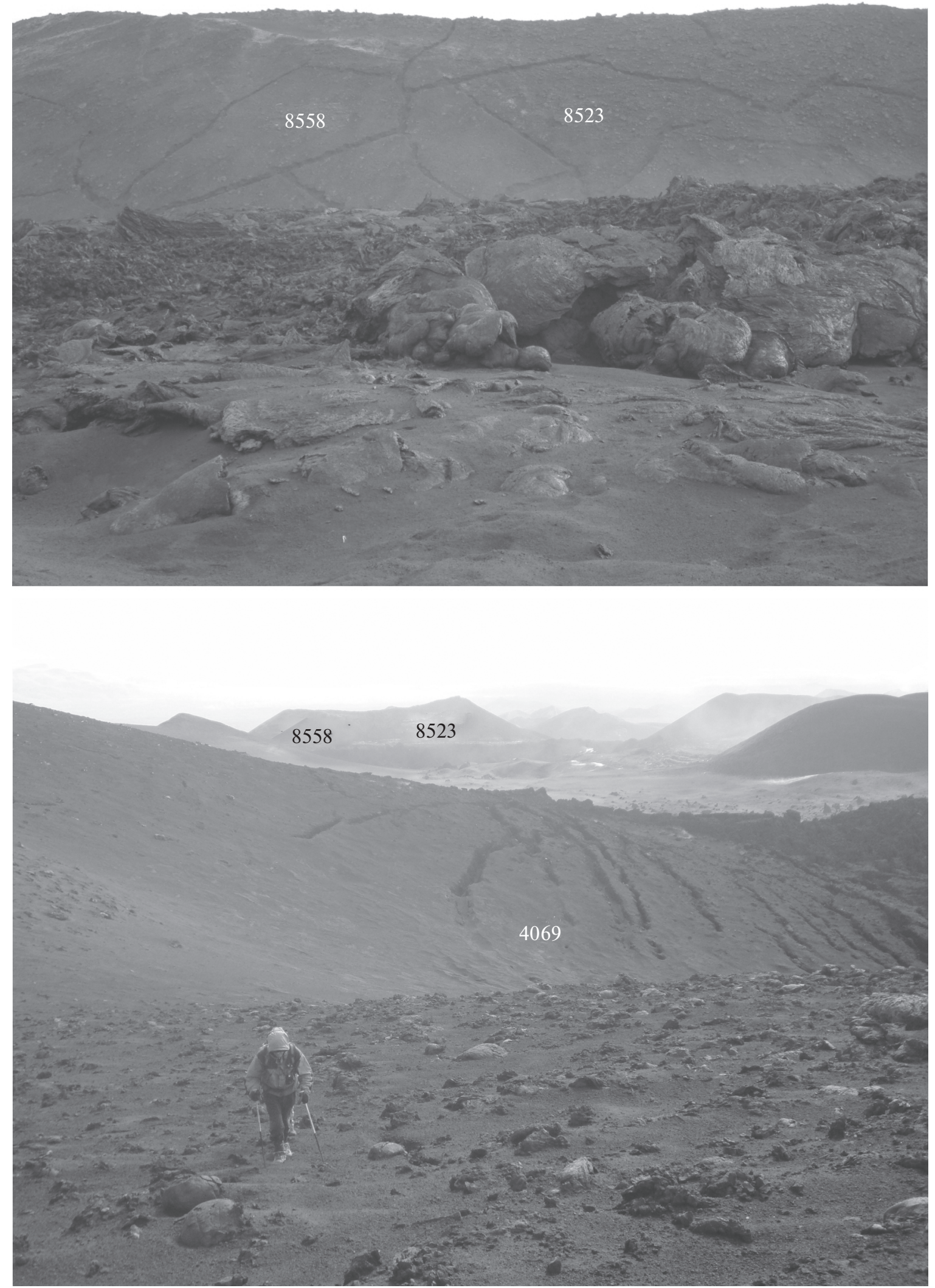
щин север-запад-северного простирания $340^{\circ} \mathrm{K}$ востоку от основной магмовыводящей трещины; 3. Распространение полигональных открытых (до 0.5-1.0 м) трещин на склонах конуса Клешня (к югу от основного эруптивного центра) (рис. 3, рис. 4). Открытые линейные трещины под углом $45^{\circ}$ к основной магмовыводящей трещине указывают на ее сдвиговый характер. Полигональные открытые трещины указывают на условия радиального растяжения, возможные при значительном превышении вертикального стресса над горизонтальным (Sv > Shmax = Shmin) [Zoback, 2010, p. 9], что может происходить при внедрении силлов.

Таким образом, хотя геомеханическая модель c одной дайкой может объяснить суммарный геодеформационный эффект, но она вряд ли адекватно описывает последовательность внедрений магматических тел, предшествуюших извержению 27.11.2012. В связи с этим, рассмотрим возможности использования данных по локальной сейсмичности для восстановления последовательности инжекции магмы перед извержением Толбачинского вулкана.

\section{2. Геомеханическая интерпретация локальной сейсмичности}

Выявленные плоско-ориентированные кластеры землетрясений (см. таблицу) интерпретируются как силлы и дайки, образовавшиеся при инжекции магмы. Если это предположение справедливо, то извержению Толбачинского вулкана предшествовало около двадцати внедрений даек при инжекции магмы (преимущественно западсевер-западного простирания) в диапазоне глубин $-4 \ldots+3$ км абс. в зоне к юго-востоку от постройки вулкана Плоский Толбачик (см. таблицу, кластеры землетрясений 18-36; рис. 5а). Это привело к вскрытию субгоризонтальных проницаемых резервуаров и формированию условий для инжекции двух силлов (0 км абс.) и магмовыводящей дайки север-восток-северного простирания $30^{\circ}$ (см. таблицу, кластеры землетрясений 37-39; рис. 5б), в результате чего началось извержение Толбачинского вулкана 27.11.2012.

Заметим, что азимут простирания магмовыводящей дайки $30^{\circ}$ (см. таблицу, кластер 38), оцениваемый по сейсмическим данным, хорошо согласуется с результатами полевых наблюдений $\left(25^{\circ}\right)$ и спутниковых геодеформационных наблюдений InSar [Lundgren et al., 2015], а кластеры 37 и 39 (см. таблицу), отождествляемые с силлами, - соответствуют наблюдениям полигональных трещин (см. рис. 3, рис. 4).
4. ГЕОМЕХАНИЧЕСКАЯ ИНТЕРПРЕТАЦИЯ: ПОСЛЕДОВАТЕЛЬНОСТЬ ИНЖЕКЦИЙ МАГМЫ В КОРЯКСКО-АВАЧИНСКОЙ ГРУППЕ ВУЛКАНОВ В ПЕРИОД 2000-2012 гГ.

\section{1. Краткая информация о парогазовом извержении Корякского вулкана 2008-2009 .} [Иванов, 2010]

Видимая активизация вулкана Корякский началась 23 ноября 2008 г. (усиление парогазовой активности в трещине на северо-западном склоне вулкана при тепловой мощности струи 40 МВт и расходе 15 кг/с водного флюида). К концу декабря тепловая мощность (определяемая по расходу пара) увеличились до 400 МВт и $150 \mathrm{Kг} / \mathrm{c}$, в шлейфе верхнего (основного) жерла появилась примесь пепла. С конца апреля активизация продолжалась как парогазовая только из основного жерла (на начало июня 2009 г.). Корякский вулкан в конце 2008 г.-начале 2009 г. выносил 50-150 кг/с пара, что соответствовало средней тепловой мощности 300-400 МВт. Верхнее, ближайшее к кратеру жерло, было основным и характеризовалось на порядок большим расходом пара, чем нижнее. В январе 2009 г. расходы пара из этих жерл составили 170 и $\sim 20$ кг/с соответственно. За четыре месяца извержения (конец декабря 2008 г.-конец апреля 2009 г.) вулкан Корякский вынес 1.5 млн т пара. Если предположить, что этот пар образовался при вскипании метеорной воды в результате охлаждения и кристаллизации магмы, то это соответствует массе как минимум 3 млн т внедрившейся магмы. Учитывая сравнительно медленное охлаждение магмы при взаимодействии ее с водой вследствие закалки, масса внедрившейся магмы могла быть на порядок больше.Тепловые мощности парогазовых шлейфов вулкана Корякский оценивались В.В. Ивановым [2010] по формуле, предложенной С.А. Федотовым.

\section{2. Геомеханическая интерпретация локальной сейсмичности}

За период с января 2000 г. по февраль 2013 г. в постройках и фундаменте Корякско-Авачинской группы вулканов по данным КФ ГС РАН зарегистрировано 3922 землетрясения. В результате обработки указанного выше набора данных по методике, изложенной в разделе 2.2, из них выделяется 1310 землетрясений, формирующих 164 плоскоориентированных кластера в период января 2008 г. по август 2011 г. 3D визуализация временной последовательности кластеров позволяет предложить следующую историю инжекции магмы в системе питающих каналов вулканов в 2008-2011 гг.

1. Инжекции магмы из глубинных (первичных) магматических очагов в интервале глубин до 10 км под Корякским и под Авачинским вулканами (январь-июнь 2008 г.). Инжекция магмы из 
(a)

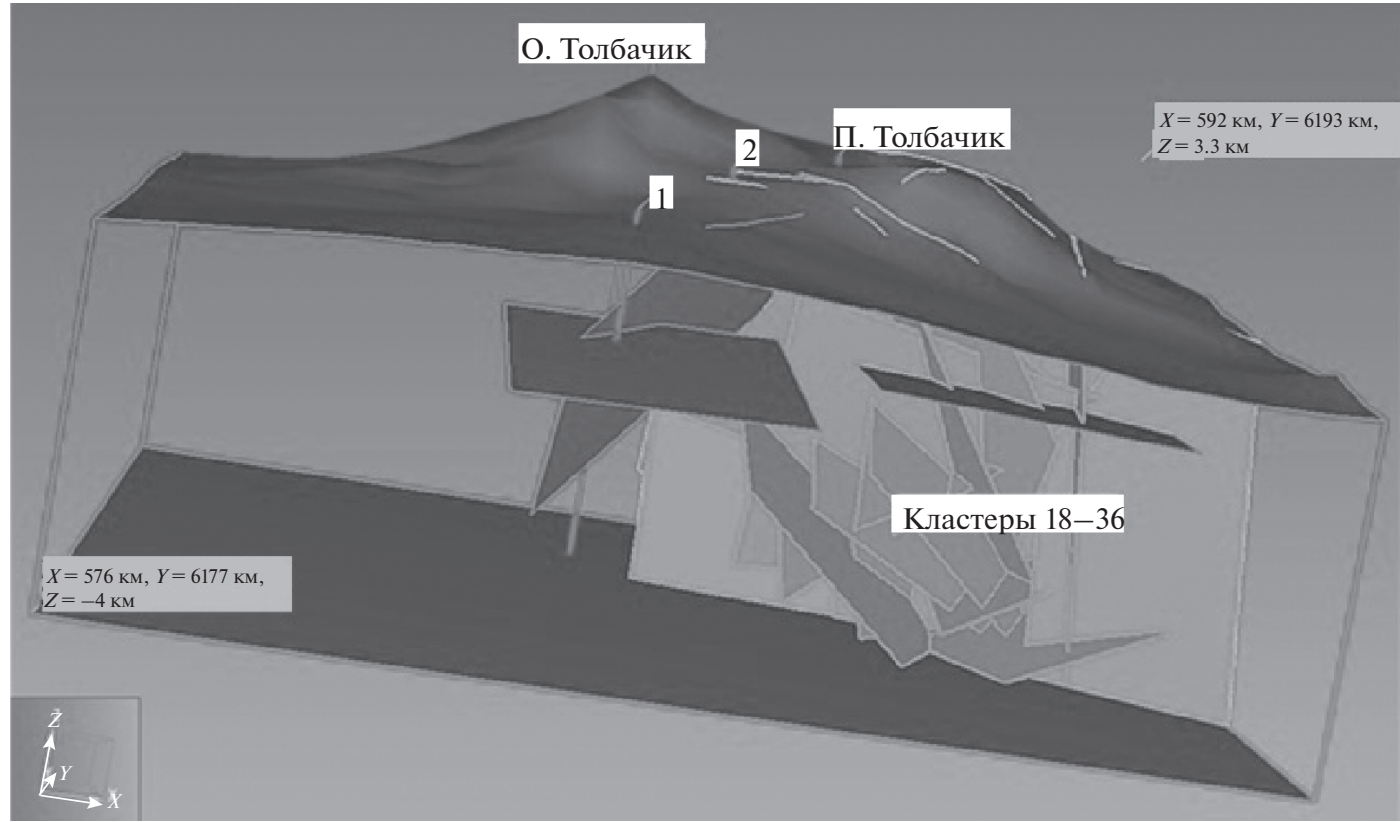

(б)

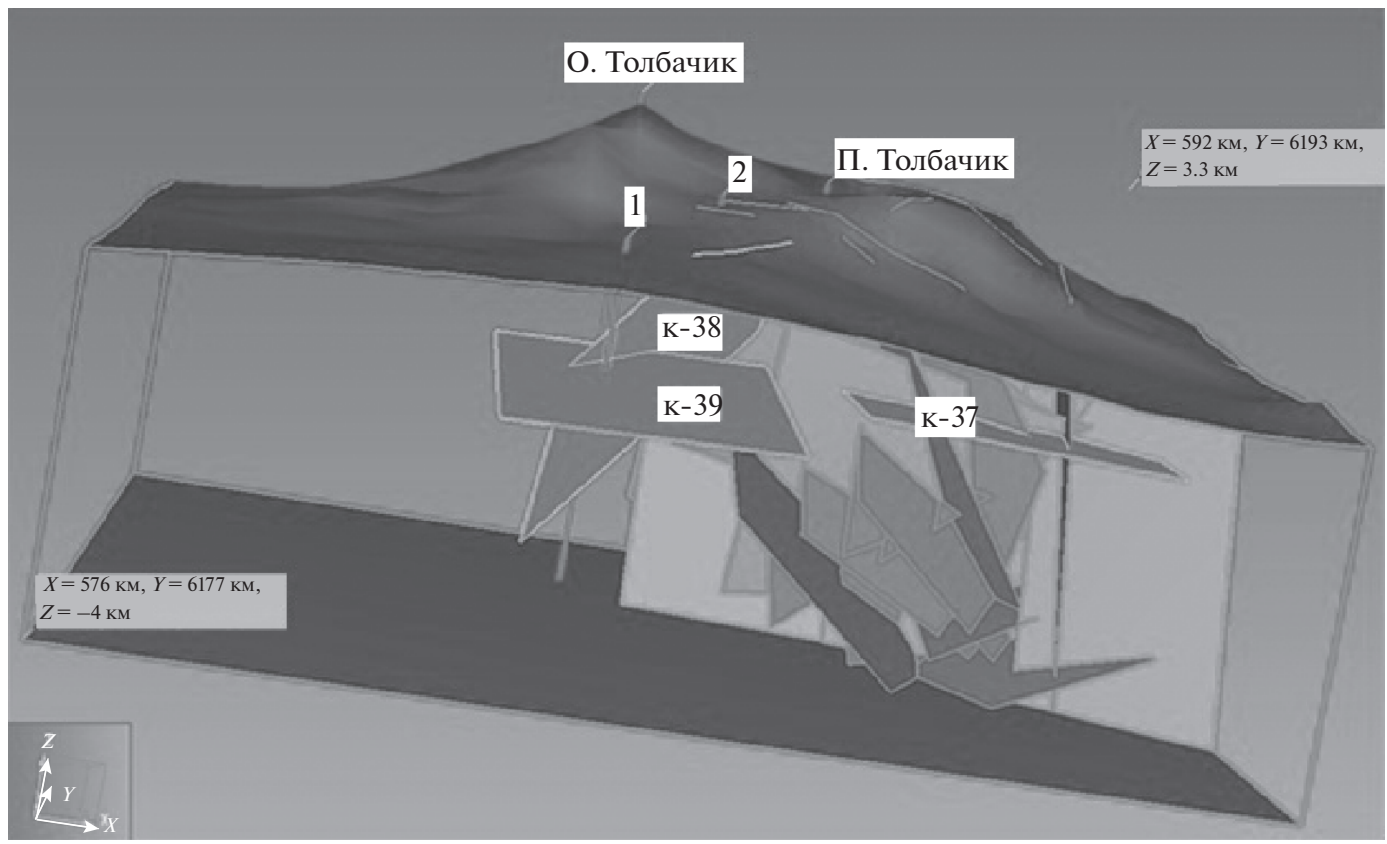

Рис. 5. Геомеханическая интерпретация локальной сейсмичности, предшествовавшей в течение двух дней началу извержения Толбачинского вулкана 27.11.2012.

На верхнем рис. 5а подсветкой выделены дайки и силлы (кластеры 18-36), образовавшиеся 25-27.11.2012 на начальном этапе при доминировании вертикальных напряжений (геомеханические условия NF: Sv $>$ Shmax $>$ Shmin). Ha нижнем рис. 5б подсветкой выделены два силла и магмовыводяшая дайка (кластеры 37-39), образовавшиеся 27.11.2012 непосредственно перед извержением при доминировании горизонтальных напряжений север-восток-северного направления (геомеханические условия: Shmax $\gg \mathrm{Sv}=\mathrm{Shmin).} 1$ - кратер Меняйлова, 2 - кратер Набоко. Плановые границы модели показаны прямоугольником на рис. 1, значения координат во вставках на рисунке в системе UTM WGC-84.

первичного магматического очага под Авачинским вулканом зафиксирована в форме субмеридиональной дайки, инжекции в конус Авачинско- го вулкана характеризуются кластерами с падением преимушественно в северном направлении с углами падения $30^{\circ}-70^{\circ}$. Инжекции магмы из пер- 
вичного магматического очага под Корякским вулканом зафиксированы в форме субмеридиональных даек, сопутствующих инжекции в промежуточный магматический очаг Корякского вулкана на глубинах -7000...-10000 м абс. также преимущественно субмеридионального простирания с углами падения $30^{\circ}-80^{\circ}$.

2. Инжекции магмы в промежуточный (коровый) магматический очаг Корякского вулкана на глубинах $-3.0 \ldots-5.5$ км абс. у его юго-западного подножия на расстоянии 1.5-4.0 км от вершины (июль 2008 г.-январь 2009 г.) (рис. 6а), сопровождавшиеся началом парогазового извержения Корякского вулкана 23 ноября 2008 г. Наполнение промежуточного очага сопровождалось образованием наклонных даек разнообразного простирания с углами падения $20^{\circ}-80^{\circ}$ (см. рис. 6а).

3. Инжекции магмы в зоне субмеридионального простирания $(7.5 \times 1.5$ км) в диапазоне глубин $-10000 \ldots+3500$ м абс. под северным склоном Корякского вулкана, сопровождающиеся активизацией вершинного парогазового извержения Корякского вулкана (февраль 2009 г.-апрель 2009 г.) (см. рис. 6б). Наполнение указанной выше субмеридиональной зоны магмой фиксировалось образованием наклонных даек преимущественно субмеридионального простирания с углами падения более $40^{\circ}$. Пять даек приближены к вершинной части Корякского вулкана.

4. Продолжение инжекции магмы в зоне субмеридионального простирания (см. выше) под северным склоном Корякского вулкана, сопровождаюшееся вершинным парогазовым извержением Корякского вулкана (апрель-май 2009 г.). Зона смещается приблизительно на 1 км в восточном направлении относительно описанной выше в п. 3. Наполнение указанной выше субмеридиональной зоны магмой фиксируется образованием наклонных даек разнообразного простирания с углами падения более $35^{\circ}$. Две дайки приближены к вершинной части Корякского вулкана.

5. Продолжение инжекции магмы в зоне субмеридионального простирания (см. выше п. 3) под северным склоном Корякского вулкана, сопровождающееся затуханием вершинного парогазового извержения Корякского вулкана (июнь 2009 г.-март 2010 г.). Наполнение указанной выше субмеридиональной зоны магмой фиксируется наклонными дайками преимущественно СС3 простирания и силами. Восемь даек приближены к вершинной части Корякского вулкана. Одна дайка направлена в сторону зоны разгрузки Корякских Нарзанов.

6. В дальнейшем инжекция магмы происходила в основном в конус Авачинского вулкана, октябрь 2010 г.-май 2011 г., там выявляются наклонные дайки преимущественно С3 простирания с углами падения до $85^{\circ}$ и силы. Один дайка фиксируется под С3 склоном Корякского вулкана в районе Изотовских источников (2.08.2011), что отразилось в увеличении температуры последнего [Кирюхин и др., 2015а].

\section{5. ОБСУЖДЕНИЕ ПОЛУЧЕННЫХ РЕЗУЛЬТАТОВ С ИСПОЛЬЗОВАНИЕМ ДИАГРАММ МОРА}

Зона распространения активных вулканов Камчатки характеризуется в целом условиями горизонтального растяжения, в которых преобладают грабенообразные структуры и сбросы (геомеханическое состояние NF (Normal Fault, вертикальные напряжения превышают горизонтальные $\mathrm{Sv}>\mathrm{SHmax}>$ $>$ SHmin)). При транспорте магмы из первичных или коровых магматических очагов формирование трещин магморазрыва осуществляется перпендикулярно направлению минимального напряжения Shmin, при этом давление флюида Pf должно превышать Shmin. Таким образом, магистральные первичные трещины, по которым осуществляется транспорт магмы, - вертикальные дайки. В случае, если давление флюида (магмы) приводит к превышению максимальных сдвиговых напряжений ( $\tau>\mu \sigma$, где $\tau-$ сдвиговое напряжение, $\sigma$ - нормальное напряжение, $\mu \approx 0.6$ коэффициент внутреннего трения), происходит активизация критически сжатых сдвиговых трещин. Углы падения указанных трещин наиболее наглядно определяются по диаграмме Мора. И наоборот, имея в распоряжении данные по углам падения активных сдвиговых трещин, можно оценить давление флюида в зоне магморазрыва.

В качестве графической иллюстрации приводится рис. 7, на котором изображены диаграммы Мора для вулканов Толбачик (состояние 2012 г.), Корякский (состояние 2008-2009 гг.) и Авачинский (2009 г.). Круги Мора являются графическим представлением напряженного состояния на различно ориентированных площадках по отношению к главным осям напряжений. Координаты кругов Мора на диаграммах рассчитываются по формулам:

$$
\begin{gathered}
\tau=0.5(\mathrm{~Sv}-\mathrm{SH} \min ) \sin (2 \beta), \\
\sigma=0.5(\mathrm{~Sv}+\mathrm{SH} \min )+ \\
+0.5(\mathrm{~S} v-\mathrm{SH} \min ) \cos (2 \beta)-\mathrm{Pf},
\end{gathered}
$$

где $\beta$ - угол падения плоско-ориентированных кластеров (см. таблицу).

Вертикальные напряжения Sv определяются во всех случаях как литостатическое давление $\left(\mathrm{Sv}=\rho \mathrm{gH}, \rho=2800 \mathrm{\kappa} / \mathrm{M}^{3}\right.$ (Gudmundsson, 2012)) в точке инжекции магмы (средняя глубина Н центров плоско-ориентированных кластеров, отождествляемых с центром магматического очага, в который осуществляется инжекция магмы), для 
(a)

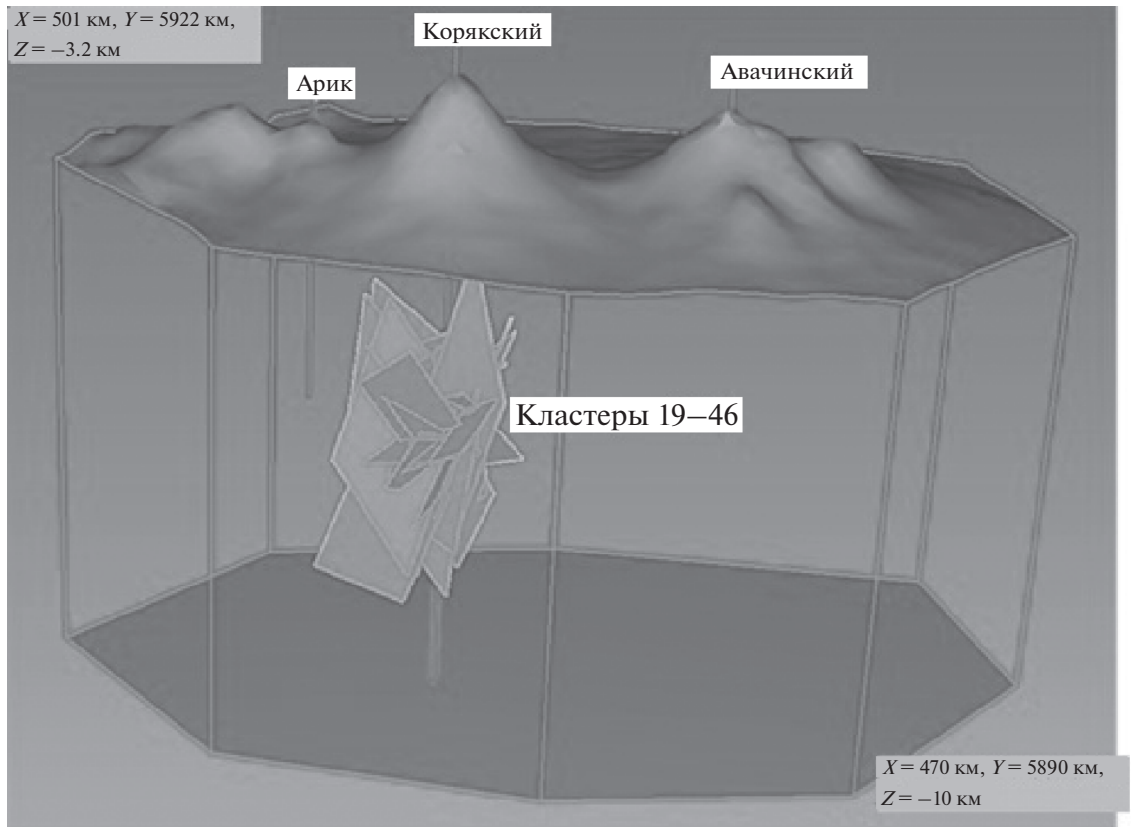

(б)

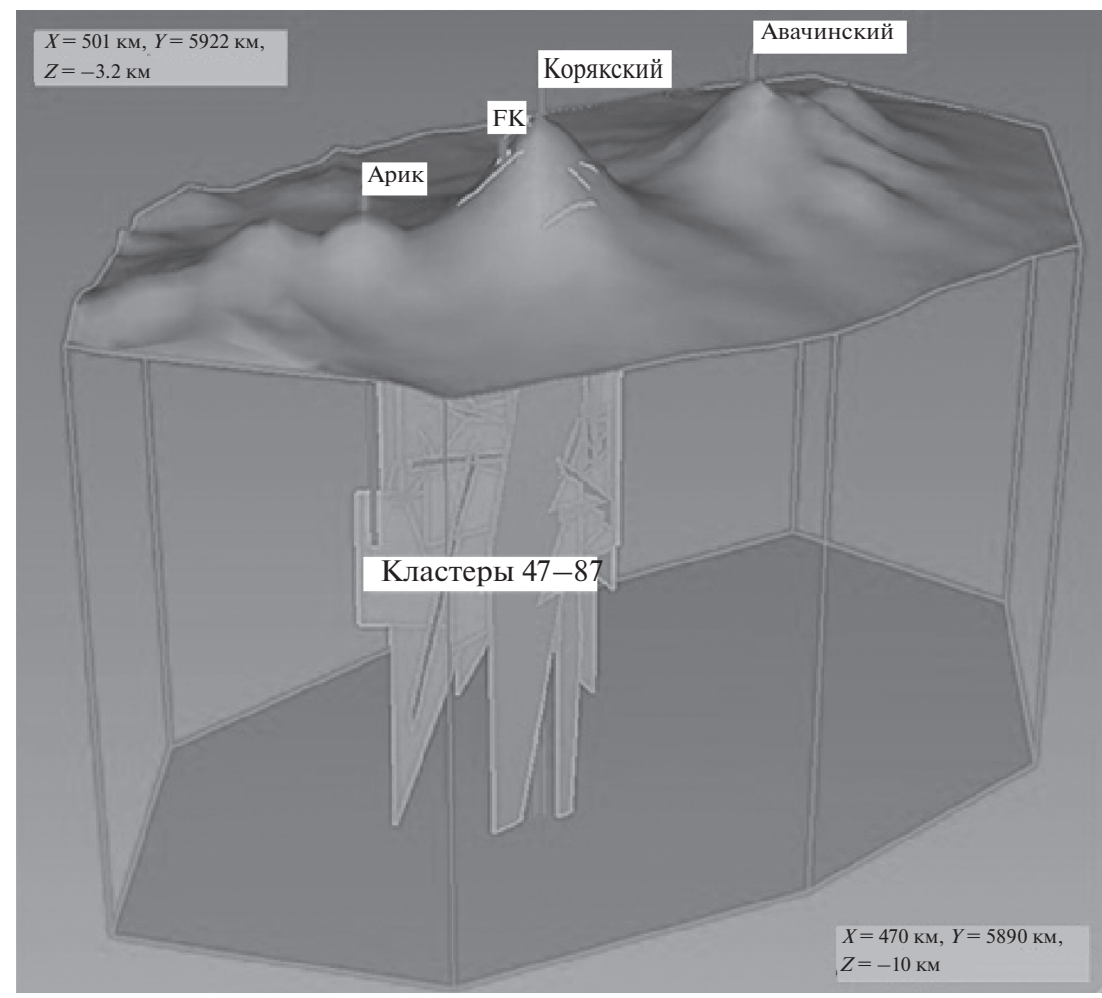

Рис. 6. Геомеханическая интерпретация локальной сейсмичности под Авачинско-Корякской группой вулканов. а - инжекции магмы в промежуточный (коровый) магматический очаг Корякского вулкана на глубинах $-3.0 \ldots-5.5$ км абс. у его юго-западного подножья (июль 2008-январь 2009 г.) (кластеры 19-46, см. рис. 7); б - инжекции магмы в зоне субмеридионального простирания под северным склоном Корякского вулкана, сопровождающиеся активизацией вершинного парогазового извержения Корякского вулкана (февраль-апрель 2009 г.) FK - Корякская фумарола. Плановые границы модели показаны многоугольником на рис. 2, значения координат во вставках на рисунке в системе UTM WGC-84. 


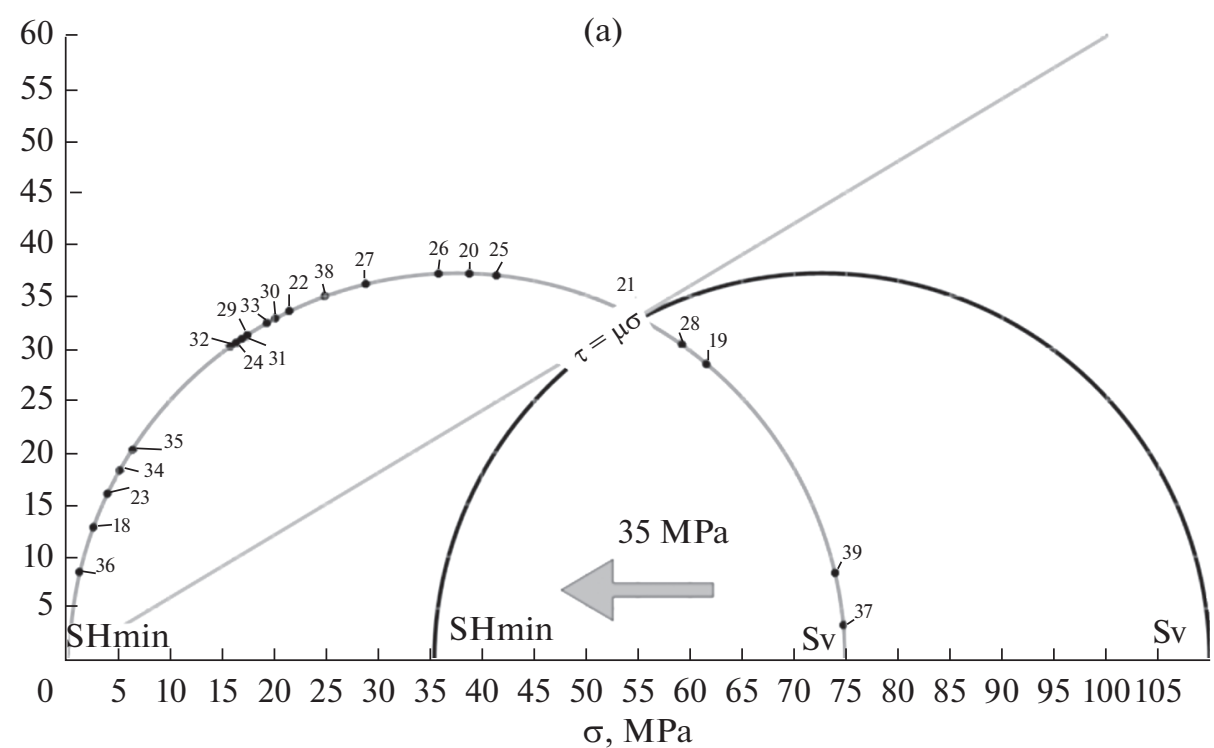

(б)

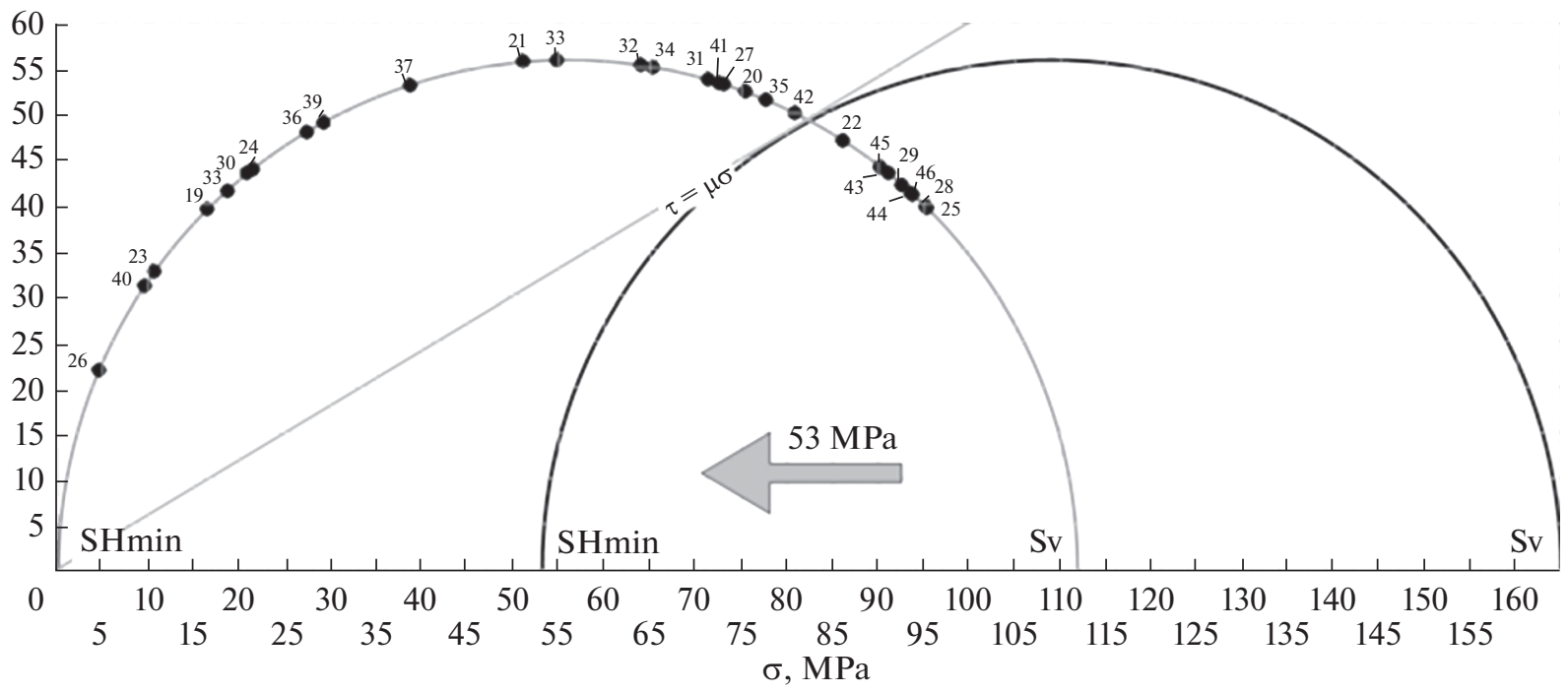

Рис. 7. Диаграммы Мора, показывающие изменение напряженного состояния при инжекции магмы.

Круг справа покрывает диапазон нормальных и сдвиговых напряжений до инжекции магмы, круг слева - после инжекции магмы; точки с номерами соответствуют активным трещинам, установленным по сейсмическим данным: а в районе вулкана Толбачик (ноябрь 2012 г., глубина 4 км); б - в районе вулкана Корякский (июль 2008-январь 2009 г., глубина 6 км). Примечание. Для позиционирования точки на круге из центра откладывается угол $2 \beta$ от горизонтальной оси (где $\beta$ - угол падения плоско-ориентированного кластера, см. колонку 2 в таблице).

вулкана Толбачик - 4 км (2012 г.), вулкана Корякский - 6 км (2008 г.), вулкана Авачинский - 1 км (2009 г.), горизонтальное напряжение SHmin определяется для условий растяжения (Normal Faults, NF) [Zoback, 2010, p. 132]:

$$
\mathrm{SHmin}=\frac{\mathrm{Sv}}{[(\mu 2+1) 0.5+\mu]^{2}} \approx \frac{\mathrm{Sv}}{3.1} .
$$

\section{1. Вулкан Толбачик (2012 г.)}

Как показывает диаграмма Мора (см. рис. 7а), для вулкана Толбачик инжекция магмы на глубине
4 км осуществлялась при давлении магмы 35 МПа и сопровождалась раскрытием трещин и образованием крутопадающих даек (см. таблицу, кластеры $18,23,34,35,36)$ с углами падения $75^{\circ}-83^{\circ}$. Синхронно происходила активизация сдвиговых трещин (кластеры 18, 20-22, 24-27, 29-33) с углами падения $32^{\circ}-62^{\circ}$, указанные трещины находятся на диаграмме Мора в зоне разрушения выше линии $\tau=\mu \sigma$. Две относительно пологие трещины (кластеры 19 и 28) с углами падения $25^{\circ}-$ $27^{\circ}$ не попадают в зону сдвигового разрушения на диаграмме Мора, возможно, они инициированы локальным стрессом на поверхности расплавлен- 
ного магматического очага. Наиболее вероятно, что все упомянутые выше дайки и трещины заполнялись магмой с формированием/восполнением частично расплавленного магматического очага, имеющего размеры до $5 \times 3.5 \times 3 \mathrm{KM}^{3}$ $\left(\approx 50 \mathrm{KM}^{3}\right)$. Прорыв магмы на поверхность произошел, когда одна из сдвиговых трещин "нашла" проницаемую субгоризонтальную зону на абс. отметке около 0 (подошва вулкана, контакт неогеновых вулканогенно-осадочных отложений и четвертичных вулканитов), что привело к формированию двух силлов (кластеры 37 и 39) и магмовыводящей дайки (кластер 38 , угол падения $55^{\circ}$ по азимуту $300^{\circ}$ ) в 5.5 км от области первичной инжекции магмы.

Заметим, что простирание магмовыводящей дайки (см. таблицу, кластер 38) и направление ее падения согласуются с результатами геомеханической интерпретации деформаций земной поверхности по спутниковым данным [Lundgren et al., 2015]. Оперяющие дайку с юга открытые субмеридиональные трещины (выявленные по результатам полевых работ в сентябре 2013 г.) свидетельствуют о наличии левосторонней сдвиговой составляющей. Наличие неглубокозалегающих силлов (см. таблицу, кластеры 37 и 39) на месте извержения - согласуется с наличием полигональных трещин на поверхности (также установленных в результате полевых исследований 2013 г.).

\section{2. Вулкан Корякский \\ (июль 2008 г.-январь 2009 г.)}

Диаграмма Мора (см. рис. 7б) показывает, что на этапе инжекции магмы в коровый магматический очаг Корякского вулкана на глубинах $-3.0 \ldots-5.5$ км абс. у его юго-западного подножия (июль 2008-январь 2009 г.) - давление магмы оценивается в 53 МПа, большая часть трещин попадает в область разрушения на диаграмме Мора и характеризуется углами падения $32^{\circ}-79^{\circ}$, т.e. вписывается в схему образования сдвиговых трещин при вертикальном гидроразрыве. Часть трещин (кластеры 22, 25, 28, 29, 43-46) имеет более пологую ориентацию $23^{\circ}-29^{\circ}$, и не может (для геомеханических условий нормальных разломов NF) быть активными. Возможность активизации пологих трещин появляется при наличии расплавленного магматического очага с размерами, сопоставимыми с размерами наблюдаемых трещин. Тогда локальный стресс по нормали к поверхности очага является максимальным и ориентация магморазрыва в радиальном направлении геомеханически возможна. Учитывая, что размеры пологих кластеров 22 и 25 оцениваются $2.2 \times 4.9$ и $3.9 \times 4.7$ км² - можно предполагать сопоставимые размеры расплавленного магматического очага, инициирующего указанные кластеры у юго-западного подножия Корякского вулкана на глубинах $-3.0 \ldots-5.5$ км абс.

\author{
5.3. Вулкан Корякский \\ (февраль 2009 г.-март 2010 г.)
}

При дальнейшей инжекции магмы под Корякским вулканом в зоне субмеридионального простирания $(7.5 \times 1.5$ км $)$ в диапазоне глубин $-10000 \ldots+3500$ м абс. под северным склоном Корякского вулкана - подавляющее количество эпизодов магморазрыва происходило в зоне, разрешенной диаграммой Мора. Это свидетельствует о том, что процесс инжекции магмы сопровождался открытием субвертикальных трещин $\left(84^{\circ}-87^{\circ}\right)$ и внедрением даек синхронно с образованием сдвиговых трещин (углы падения $34^{\circ}-82^{\circ}$ ). Наибольшая плотность магморазрыва наблюдалась в объеме $7.5 \times 1.5 \times 4$ км $\left(45\right.$ км$\left.^{3}\right)$, который насыщался магматическим расплавом в различной степени. Наличие более пологих кластеров с углами падения $4^{\circ}-30^{\circ}$, не попадающих в зону сдвигового разрушения, указывает на возможность существования локальных расплавленных магматических очагов в указанном выше объеме, способных создавать локальный стресс с потенциалом гидроразрыва в радиальном направлении.

\section{4. Вулкан Авачинский \\ (октябрь 2010 г.-май 2011 г.)}

Инжекция магмы в конус Авачинского вулкана началась после безуспешных попыток магмы прорваться на поверхность через систему магмопроводящих каналов Корякского вулкана. Судя по характеристикам плоско-ориентированных кластеров микроземлетрясений, оценкам горизонтальных напряжений - инициирование субвертикальных открытых трещин и формирование даек произошло при давлении более 9 МПа в конусе вулкана на глубине около 1 км. Наличие многочисленных субгоризонтальных кластеров с углами падения $2^{\circ}-15^{\circ}$ указывает на существование стратиформных структур, по которым происходила утечка магматического расплава из питающего канала и формирование силлов в диапазоне отметок $+1600 \ldots+1900$ м абс. в конусе Авачинского вулкана.

\section{ЗАКЛЮЧЕНИЕ}

1. На примере трещинного базальтового извержения Толбачинского вулкана 2012-2013 гг., парогазового извержения Корякского вулкана 2008-2009 гг. и активизации Авачинского вулкана в 2010 г. (Камчатка) показано, что каталоги локальных землетрясений, связанных с извержениями вулканов, содержат плоско-ориентированные кластеры гипоцентров. Их можно интерпретировать как зоны формирования силлов и даек, происходящего при внедрении магм, магморазрыве вмещающих горных пород под вулканами во время подготовки и при развитии извержений. 
A

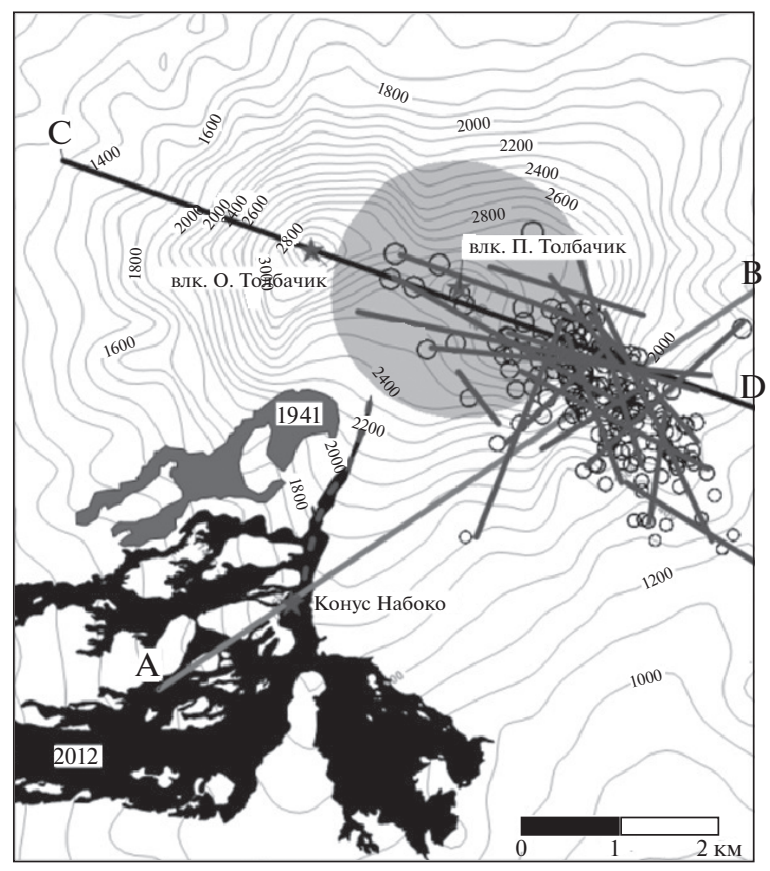

(б)
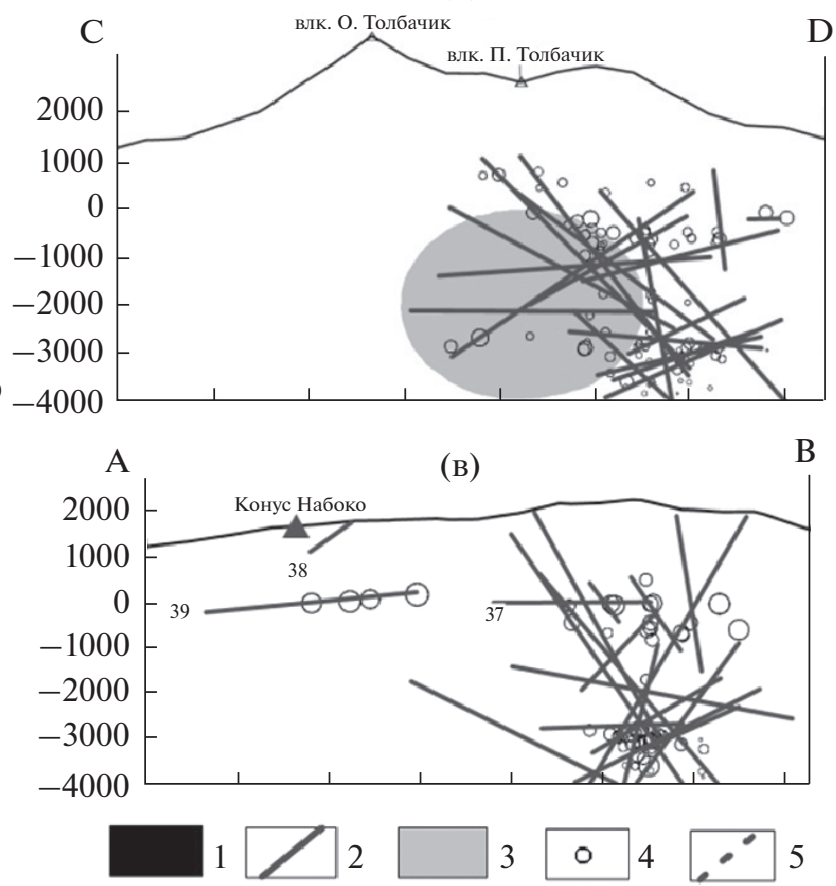

Рис. 8. Положение даек и силлов, образовавшихся в районе вулкана Плоский Толбачик 25-27.11.2012 перед Толбачинским трещинным извержением 27.11.2012 в горизонтальном срезе на глубине 3 км абс. (рис. 8а), и в плоскостях вертикальных разрезов АВ и СD ( рис. 8б и 8в). Границы участка рис. 8а показаны прямоугольником на рис. 1.

1 - контуры лавовых потоков Толбачинского извержения 2012-2013 гг. [Volynets et al., 2013], см. рис. 1;2 - следы плоско-ориентированных кластеров (зоны внедрения крутопадающих даек, см. таблицу) на горизонтальном срезе - 3 км абс. и в плоскостях вертикальных разрезов АB и CD; 3 - проекция контуров периферического магматического очага, с размерами, указанными в статье [Федотов и др., 2011] на горизонтальном срезе - 3 км абс. и в плоскости вертикального разреза CD; 4 - проекции центров локальных землетрясений на горизонтальный срез - 3 км абс. и вертикальные разрезы $\mathrm{AB}$ и $\mathrm{CD}$ (показаны только центры землетрясений на расстоянии от плоскостей до 1 км); 5 - эруптивная трещина ТТИ 27.11.2012. Изолиниями показана топографическая поверхность, номерами на разрезе АВ показаны магмовыводящие силлы (37 и 39) и дайка (38) (нумерацию см. таблицу), разметка по горизонтальным осям - 2 км.

2. В районе Толбачинских вулканов выделяется 22 плоско-ориентированных кластера землетрясений, предшествовавших в течение двух дней началу извержения вулкана 27.11.2012. Выявленные плоскости интерпретируются как зоны внедрения даек и силлов при инжекции магмы. Исходя из указанной интерпретации, извержению Толбачинского вулкана предшествовало внедрение крутопадающих даек запад-север-западного простирания с углами падения $32^{\circ}-62^{\circ}$ при давлении магмы 35 МПа (на глубине 4 км) в диапазоне глубин -4...+3 км абс. к юго-востоку от постройки вулкана Плоский Толбачик на площади $5 \times 3.5 \mathrm{kM}^{2}$. Прорыв магмы на поверхность произошел после вскрытия проницаемой субгоризонтальной зоны на абс. отметке около нуля, что привело к формированию двух силлов и магмовыводящей дайки (угол падения $55^{\circ}$ по азимуту $300^{\circ}$ ), которое произошло в юго-западной радиальной зоне трещин и шлаковых конусов Плоского Толбачика в 7 км от середины области предшествовавших внедре- ний (см. рис. 1 и рис. 8). Установленный механизм перемещения магм к поверхности согласуется с результатами полевых измерений трещиноватости на месте извержения в 2013 г. и результатам интерпретации деформаций земной поверхности по спутниковым данным [Lundgren et al., 2015]. Зоны плоско-ориентированных кластеров на горизонтальном срезе -3 км абс. и в плоскостях вертикальных разрезов примыкают к области периферического магматического очага, предполагаемого в работах С.А. Федотова и др. [2011] (рис. 8), и являющегося вероятным источником магмы лавового извержения Толбачинского вулкана 2012-2013 гг.

3. Вершинное парогазовое извержение Корякского вулкана 2008-2009 гг. сопровождалось 153-мя плоско-ориентированными кластерами землетрясений, интерпретируемыми как зоны внедрения даек и силлов при инжекции магмы. Подготовка извержения началась с насыщения магмой корового очага (глубина кровли -3 км абс., поперечник 2.5 км) у юго-западного подножия Коряк- 
ского вулкана (июль 2008 г.-январь 2009 г.). Далее инжекция магмы в субмеридиональной зоне $(7.5 \times$ $\times 2.5$ км, основной диапазон глубин $-2 . . .-5$ км абс.) в северном секторе Корякского вулкана происходила параллельно с наиболее интенсивным периодом вершинного парогазового извержения (февраль 2009 г.-март 2010 г.). Процесс инжекции магмы при давлении 53 МПа (на глубине 6 км) сопровождался внедрением даек $\left(84^{\circ}-87^{\circ}\right)$ синхронно с образованием наклонных даек (углы падения $\left.34^{\circ}-82^{\circ}\right)$. Наибольшая плотность магморазрыва наблюдалась в объеме $45 \mathrm{kM}^{3}$, который насыщался магматическим расплавом в различной степени. Наличие более пологих кластеров с углами падения $4^{\circ}-30^{\circ}$ не попадающих в зону сдвигового разрушения на диаграмме Мора указывает на возможность существования локальных расплавленных магматических очагов и проницаемых стратиформных резервуаров в указанном выше объеме. После насыщения магматической питающей системы Корякского вулкана произошла инжекция магмы в конус Авачинского вулкана (2010 г.).

Качество и полнота имеющихся исходных данных, точность координат гипоцентров, которые определяют возможности данного исследования механизма деятельности трех вулканов (Плоского Толбачика и Корякско-Авачинской группы) определяются каталогами, предоставляемыми КФ ГС РАН, работа над уточнением которых и координат гипоцентров землетрясений продолжается. Поэтому некоторые изложенные выше результаты являются предварительными и могут быть уточнены после получения более полных и точных данных о координатах очагов землетрясений.

Авторы выражают признательность за помощь в организации полевых работ, обработке и обсуждении полученных результатов Т.В. Рычковой, В.К. Григорьеву, Н.Б. Журавлеву, Р. Lundgren, S. Samsonov, А.Б. Белоусову, М.Г. Белоусовой, Т.Г. Чуриковой, И.К. Дубровской, Д.В. Мельникову, Я.Д. Муравьеву, В.Н. Чеброву, И.Ф. Делеменю, В.К. Лемзикову, С.Л. Сенюкову и В.В. Иванову.

Работа выполнена при поддержке по проекту РНФ № 16-17-10008.

\section{СПИСОК ЛИТЕРАТУРЫ}

Большое трещинное Толбачинское извержение / Отв. редактор Федотов С.А. М.: Наука, 1984. 637 с.

Землетрясения России в 2012 г. Обнинск: ГС РАН, 2014. $223 \mathrm{c}$

Иванов В.В. Активизация вулкана Корякский (Камчатка) в конце 2008-начале 2009 г.: оценки выноса тепла и водного флюида, концептуальная модель подъема магмы и прогноз развития извержения // Матер. конф., посвященной Дню вулканолога, 30-31 марта 2009 г. Петропавловск-Камчатский: ИВиС ДВО PAH, 2010. C. 24-39.

Иванов В.В. Роль флюидов в образовании микроземлетрясений на вулканах и геотермальных системах // Тезисы XVIII ежегодной науч. конф., посвященной Дню вулканолога "Вулканизм и связанные с ним процессы” 30 марта-1 апреля 2015 г. Петропавловск-Камчатский: ИВиС ДВО РАН, 2015. С. 164-169.

Кирюхин А.В., Манухин Ю.Ф., Федотов С.А. и др. Геофлюиды Авачинско-Корякского вулканогенного бассейна, Камчатка // Геоэкология. Инженерная геология. Гидрогеология. Геокриология. 2015а. № 4. С. 306-320.

Кирюхин А.В., Федотов С.А., Кирюхин П.А. Геомеханическая интерпретация локальной сейсмичности, предшествовавшей извержению Толбачинского вулкана 27.11.2012 // Сборник 18-й конференции, посвященной Дню вулканолога. Петропавловск-Камчатский: ИВиС ДВО РАН, 2015б. С. 266-269.

Кугаенко Ю.А., Салтыков В.А., Воропаев П.В. Анализ сейсмичности, предварявшей Трешинное Толбачинское извержение 2012-2013 гг. // Землетрясения России в 2012 г. Обнинск: ГС РАН, 2014. С. 82-86.

Кугаенко Ю.А., Титков Н.Н., Салтыков В.А., Воропаев П.В. Анализ подготовки трешинного Толбачинского извержения 2012-2013 гг. в параметрах сейсмического режима и деформаций земной коры по данным системы комплексного мониторинга активности вулканов Камчатки // Вулканология и сейсмология. 2015. № 4. C. $40-58$.

Сенюков С.Л., Нуждина И.Н., Чебров В.Н. Вулканы Камчатки // Землетрясения России в 2012 г. Обнинск: ГС РАН, 2014. С. 77-81.

Федотов С.А., Балеста С.Т., Двигало В.Н. и др. Новые Толбачинские вулканы // Активные вулканы Камчатки. Т. 1. М.: Наука, 1991. С. 275-279.

Федотов С.А. Магматические питающие системы и механизм извержений вулканов. М.: Наука, 2006.456 с

Федотов С.А., Сугробов В.М., Уткин И.С., Уткина Л.И. Возможности использования тепла магматического очага Авачинского вулкана и окружающих его пород для тепло- и электроснабжения // Вулканология и сейсмология. 2007. № 1. С. 32-46.

Федотов С.А., Уткин И.С., Уткина Л.И. Периферический магматический очаг базальтового состава вулкана Плоский Толбачик, Камчатка: деятельность, положение и глубина, размеры и их изменения по данным о расходе магм // Вулканология и сейсмология. 2011. № 6. C. 3-20.

Федотов С.А., Славина Л.Б., Сенюков С.Л., Кучай М.С. Сейсмические процессы и перемещение магм, происходившие при Большом трещинном Толбачинском извержении 1975-1976 гг. и Трещинном Толбачинском извержении 2012-2013 гг. (п-ов Камчатка) // Геофизические процессы и биосфера. 2014. Т. 11. № 1. C. $3-30$.

Belousov A., Belousova M., Edwards B. et al. Overview of the precursors and dynamics of the 2012-2013 basaltic fissure eruption of Tolbachik Volcano, Kamchatka, Russia // J. Volcanol. and Geotherm. Res. 2015. № 307. P. 22-37.

Gudmundsson A. Magma chambers: Formation, local stresses, excess pressures, and compartments // J. Volcanol. and Geotherm. Res. 2015. № 237-238. P. 19-41. 
Lundgren P., Kiryukhin A., Milillo P., Samsonov S. Dike model for the 2012-2013 Tolbachik eruption constrained by satellite radar interferometry observations // J. Volcanol. and Geotherm. Res. 2015. № 307. P. 79-88.

Senyukov S.L., Nuzhdina I.N., Droznina S.Ya. et al. Seismic monitoring of the Plosky Tolbachik eruption in 2012-2013 (Kamchatka Peninsula Russia) // J. Volcanol. and Geotherm. Res. 2015. № 307. P. 47-59.

Sigmundsson F., Hooper A., Hreinsdorttir S. et al. Segmented lateral dyke growth in a rifting event at Barrparbunga volca- nic system, Iceland // Nature. 2015. V. 517. P. 191-194. doi $10.1038 /$ nature 14111

Volynets A.O., Melnikov D.V., Yakushev A.I. First data on composition of the volcanic rocks of the IVS 50th anniversary Fissure Tolbachik eruption (Kamchatka) // Doklady Earth Sciences. 2013. V. 452(1). P. 953-957. doi 10.1134/S1028334X13090201

Zoback M.D. Reservoir Geomechanics. Cambridge: University Press, 2010. 448 p. 